\title{
Chapter 9 \\ Commercial Potential of Microbial Inoculants for Sheath Blight Management and Yield Enhancement of Rice
}

\author{
K. Vijay Krishna Kumar, M.S. Reddy, J.W. Kloepper, K.S. Lawrence, \\ X.G. Zhou, D.E. Groth, S. Zhang, R. Sudhakara Rao, Qi Wang, \\ M.R.B. Raju, S. Krishnam Raju, W.G. Dilantha Fernando, H. Sudini, B. Du, \\ and M.E. Miller
}

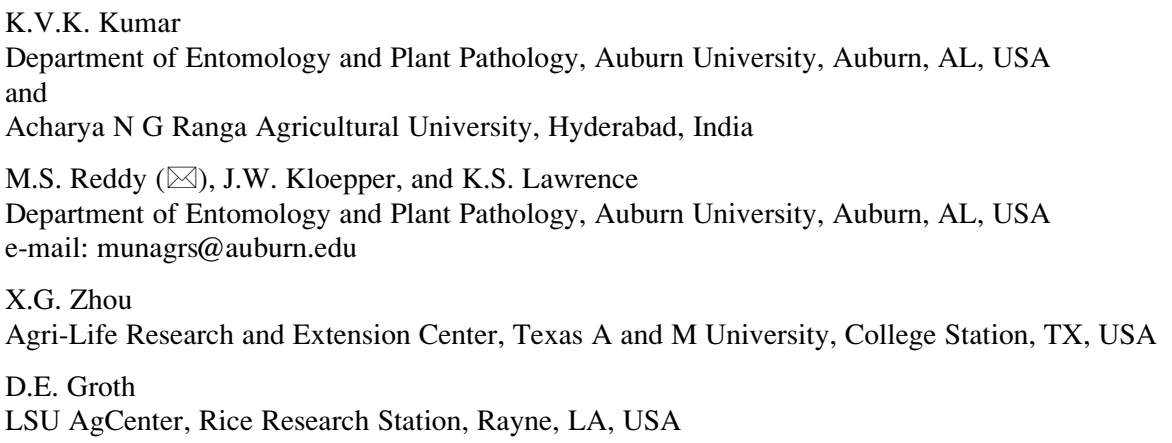

S. Zhang

Tropical REC, University of Florida, Homestead, FL, USA

R.S. Rao

Acharya N G Ranga Agricultural University, Hyderabad, Andhra Pradesh, India

Q. Wang

China Agricultural University, Beijing, China

M.R.B. Raju and S.K. Raju

Andhra Pradesh Rice Research Institute, Maruteru, Andhra Pradesh, India

W.G.D. Fernando

Department of Plant Science, University of Manitoba, Winnipeg, MB, Canada

H. Sudini

International Crops Research Institute for the Semi-Arid Tropics (ICRISAT), Hyderabad, Andhra Pradesh, India

B. Du

Department of Microbiology, Shandong Agricultural University, Taian, Shandong Province, China

M.E. Miller

Department of Biological Sciences, Auburn University, Auburn, AL, USA 


\subsection{Introduction}

Rice (Oryza sativa L.) is an important staple food crop for a larger part of the world's population and is produced around the globe. Global rice production was approximately 680 million tons in 2009 . More than $90 \%$ of rice is produced in Asia, with China and India being the lead producers. The other major rice-producing countries are Indonesia, Bangladesh, Vietnam, Thailand, Myanmar, Philippines, Brazil, and Japan (Table 9.1). Rice production in the USA, which started 300 years ago, now has an annual production of 9.2 million tons. Major rice-producing states of the USA are Arkansas, California, Louisiana, Mississippi, Missouri, and Texas. The forecasted increase in global population in the coming years is demanding a need for increase in productivity of rice, although there is only a limited scope for expansion of crop-growing area especially in densely populated countries such as Asia (Meunchang et al. 2006). Use of chemical fertilizers for enhancing rice production is a common practice. However, indiscriminate use of chemical fertilizers to increase grain yields in rice has several concerns such as leaching of fertilizers into ground water, change of microbial balance in soil-root-ecosystem, increased susceptibility of the crop to pests and diseases, and acidification or alkalization of soils.

Rice production is affected by many biotic and abiotic stresses including fungal pathogens that attack the crop from seeding to harvest and cause severe yield losses. Seed-borne pathogens often reduce the germination and inflict qualitative and quantitative yield losses (Haque et al. 2007). Among important fungal diseases, blast (Magnaporthe oryzae, formerly M. grisea or Pyricularia oryzae), sheath blight (Rhizoctonia solani AG 1-1A), brown spot (Bipolaris oryzae), sheath rot (Acrocylindrium oryzae), stem rot (Sclerotium oryzae), and bakane (Gibberella fujikuroi) cause severe yield losses in rice. Major bacterial diseases include bacterial leaf blight (Xanthomonas campestris pv. oryzae) and bacterial leaf streak (X. campestris pv. oryzicola) (Bangura and John 1991). Important viral diseases include tungro, grassy stunt, ragged stunt, yellow dwarf, orange leaf, and hoja

Table 9.1 Production details of major rice-producing countries in the world ${ }^{\mathrm{a}}$

\begin{tabular}{lll}
\hline Rank & Country & Rice production (million tons) \\
\hline 1 & China & 187.40 \\
2 & India & 144.57 \\
3 & Indonesia & 57.15 \\
4 & Bangladesh & 43.06 \\
5 & Viet Nam & 35.94 \\
6 & Thailand & 32.10 \\
7 & Myanmar & 31.45 \\
8 & Philippines & 16.24 \\
9 & Brazil & 11.06 \\
10 & Japan & 10.89 \\
\hline
\end{tabular}

${ }^{\mathrm{a}}$ FAOSTAT 2007 
blanca. Other important ones include diseases caused by nematodes such as white tip (Aphelenchoides besseyi) and ufra (Ditylenchus angustus) (Datta 1981).

Sheath blight $(\mathrm{ShB})$ is an economically significant disease of rice in all growing areas of the world. Yield losses of up to $50 \%$ are reported when susceptible varieties are grown (Prasad and Eizenga 2008). Soil bacteria in rice ecosystems typically exert a significant fungistatic effect on mycelia and sclerotia of the ShB pathogen (Luo et al. 2005). Effective management of ShB with PGPR application has been reported (Mew and Rosales 1986; Vasantha Devi et al. 1989; Kanjanamaneesathian et al. 1998); however, the field results were not consistent due to varying reasons. This review focuses on recent developments in the management of rice ShB with PGPR. The topics covered in the chapter include PGPR application in rice, greenhouse, and field efficacy of PGPR and the scope of applying them in conjunction with chemical fungicides under integrated disease management system (IDM) of $\mathrm{ShB}$. The overall goal of this chapter is to introduce the multistep process that leads to the development of a new microbial inoculant product and its use and to outline the beneficial strategies specifically for ShB disease management of rice. In addition, it attempts to define the major efforts under way to help stimulate the process. Because product development is integrally related to several tasks including intellectual property issues and to regulatory and liability concerns, these topics are also included. Data on product development for rice ShB management are not systematically available. We have, therefore, used information based on our own research efforts and, when possible, made comparisons.

\subsection{Symptomatology}

Initial ShB symptoms appear on lower rice leaf sheaths when the crop is in late tillering or early internode elongation phase. These lesions appear as green-grey water soaked at $0.5-3 \mathrm{~cm}$ below the collar region as circular, oblong, or ellipsoid and about $1 \mathrm{~cm}$ long. As the disease progresses, the lesions expand with bleached appearance and a brown border. Under favorable conditions (95\% relative humidity and temperature of $28-32^{\circ} \mathrm{C}$ ), the disease spreads by runner hyphae to upper parts of plants including leaf blades (Fig. 9.1a). The pathogen also infects the panicle (Fig. 9.1b) and causes chaffiness of lower grains (Lee and Rush 1983).

\subsection{Disease Cycle}

The pathogen survives from one crop season to another as sclerotia and mycelia in plant debris and also through weed hosts in tropical environments (Kobayashi et al. 1997). In temperate regions, the primary source of inoculum is sclerotia produced in previous rice crops (Kozaka 1961). The sclerotia float in water during field preparation and attack newly planted crop. The pathogen produces lesions on 

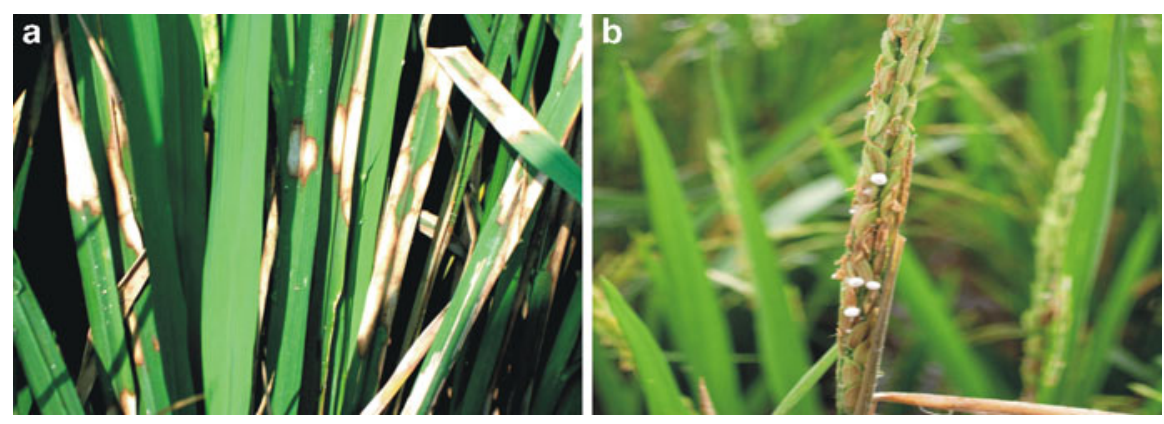

Fig. 9.1 Sheath blight symptoms on rice leaf blades and panicle (a) leaf blades. (b) Formation of sclerotia on panicle

leaf sheaths and leaf blades. The disease is more aggressive when the crop advances to the reproductive phase, and the pathogen also infects the rice panicles. New sclerotia are produced as the lesions mature and these sclerotia drop into the soil during harvesting, perpetuate, and infect a newly planted crop in the next season (Suparyono et al. 2003).

\subsection{Use of Microbial Inoculants}

Currently, ShB is managed through cultural and chemical control methods. Mostly, disease management is through use of systemic and non-systemic fungicides. Most widely used fungicides include azoxystrobin, hexaconazole, propiconazole, tebuconazole, carbendazim, trifloxystrobin, validamycin, and jinggangmycin. Use of chemicals in ShB management is creating concerns over environmental pollution, escalated costs, and pathogen resistance to chemicals. Biological control is a viable alternative in ShB disease management. However, the use of biocontrol agents in managing rice diseases is still at its infancy due to varying reasons. A successful bioagent, when applied to rice ecosystem, should be able to survive, establish, proliferate, and control target pathogens. Fungal and bacterial biocontrol agents have been used for control of rice diseases. The popularly used fungal bioagents against ShB include Trichoderma spp. and Gliocladium spp. These bioagents were applied either as seed treatment, root dip, or foliar spray (Nagaraju et al. 2002). The other effective fungal bioagent is Helminthosporium gramineum that produces a toxin called "ophiobolin." The toxin is effective in reducing ShB incidence under field conditions (Duan et al. 2007). The prevailing anaerobic conditions in rice are unfavorable for the fungal bioagents to survive, establish, and proliferate in the soil.

Rice ecosystems are rich in bacteria (Yin and Mew unpublished data; Mew et al. 2004). They also have greater adaptability to rice ecosystems compared to fungal antagonists. Of them, plant growth-promoting rhizobacteria (PGPR) have been 
used in controlling rice diseases. Besides, these PGPR also contribute to enhanced growth of the seedlings, induction of systemic resistance against diseases and thereby increases yields (Pathak et al. 2004). Bacterial strains of the genera such as Aeromonas, Azoarcus, Azospirillum, Azotobacter, Arthobacter, Bacillus, Clostridium, Enterobacter, Gluconacetobacter, Klebsiella, Pseudomonas, and Serratia were identified as PGPR (Tripathi et al. 2005; Raj et al. 2004; Dey et al. 2004; Jaizme-vega et al. 2004; Joo et al. 2004; Bonaterra et al. 2003; Cezon et al. 2003; Esitken et al. 2003; Garica et al. 2003; Munir et al. 2003; Kokalis-Burelle et al. 2002; Khalid et al. 2003; Murphy et al. 2003; Preeti et al. 2002; Gupta et al. 1995; Bertand et al. 2001; Hamaoui et al. 2001; NandaKumar et al. 2001b; Pan et al. 1999; Arndt et al. 1998; De Freitas et al. 1997; Shishido et al. 1996; Babalola et al. 2003; Mirza et al. 2001; Podile and Kishore 2006). In addition to enhancement in plant growth, PGPR were also contributed to increase $\mathrm{N}$ uptake, phytohormone synthesis, phosphate solubilization, and acquisition of ferric iron through production of siderophores (Lalande et al. 1989; Glick 1995; Bowen and Rovira 1999).

Use of PGPR in rice to control major diseases and to enhance yields was earlier reported (Lucas et al. 2009). A variety of beneficial bacteria were found to colonize the rhizosphere and aerial parts of rice. Nitrogen-fixing activity and indoleacetic acid (IAA) production was detected in roots and submerged shoots of field-grown rice due to these beneficial bacteria (Mehnaz et al. 2001). Rhizosphere bacterial isolates of rice have an excellent potential of producing biofertilizers. Inoculation of PGPR in rice increased total dry weight of plants, total $\mathrm{N}$ and $\mathrm{P}$ uptake through $\mathrm{N}$ fixation, $\mathrm{P}$ solubilization capacity, and IAA production (Meunchang et al. 2006). Use of biofertilizers in cereals was found to significantly increase plant growth and yields (Boddey et al. 1986; Fages 1994; Kapulnik et al. 1981; Kennedy and Tchan 1992; Pereira et al. 1988). Frequent rhizosphere colonizers of cereal crops and grasses include N-fixing bacteria such as Azospirillum, Acetobacter, Azoarcus, Herbaspirillum spp. (Baldani et al. 1986; Bally et al. 1983; Bilal et al. 1990; Dobereiner and Day 1976; Gillis et al. 1989; Reinhold-Hurek et al. 1993), Aeromonas, and Enterobacter spp. (Mehnaz et al. 2001).

\subsubsection{Mode of Delivery}

Field efficacy of a PGPR strain partly depends on the method of delivery. PGPR and their formulations are generally delivered as seed treatment, soil amendment, or root dip in bacterial suspensions prior to transplanting. Other important methods also include foliar spray or through drip irrigation in different crops (Podile and Kishore 2006). Success of the PGPR strain is dependent on understanding the use of specific delivery system and its advantages over other methods. In rice, PGPR is delivered through seed, as soil amendment, seedling dip, and foliar spray, and through combinations of these methods. Against rice $\mathrm{ShB}$, the popular delivery systems are through seed, soil, and foliar applications (Nakkeeran et al. 2005). 


\subsubsection{Seed Treatment}

An ideal bacterial antagonist when treated to seed should colonize the rhizosphere during seed germination (Weller 1983), and several application methods can be used to accomplish this. Treating seeds with different PGPR was found to be highly effective in managing rice ShB disease. Seed coating of $P$. fluorescens (B41) was found to be comparatively more effective than soil drenching and foliar sprays against ShB under greenhouse conditions (Kazempour 2004). Seed bacterization of Pseudomonas strain GRP3 followed by root dipping resulted in ShB reduction in rice up to $46 \%$ (Pathak et al. 2004). Seed treatment with PGPR mixtures also resulted in effective ShB management. Soaking rice seeds in $P$. fluorescens mixture of strains PF1 and PF2 at $10^{8} \mathrm{cfu} \mathrm{g}^{-1}$ for $24 \mathrm{~h}$ were effective in reducing ShB incidence under field conditions (Nandakumar et al. 2001a). Seed bacterization with fluorescent Pseudomonads such as $P$. fluorescens and $P$. putida V14i was highly effective in reducing ShB severities by 68 and 52\%, respectively, in seed bed and field experiments (Malarvizhi 1987) due to protection of the plants from infection. Subsequent planting in the same field after planting the first crop, in which the seeds were treated with bacteria, also showed reduced ShB severity (Mew and Rosales 1986). Seed treatment with peat-based formulation of $P$. fluorescens (PfALR2) at the rate of $20 \mathrm{~g} \mathrm{~kg}^{-1}$ resulted in ShB disease control effectively under greenhouse and field conditions (Rabindran and Vidhyasekaran 1996). Induced systemic resistance, plant growth promotion, and sheath blight control was observed by treating rice seeds with three isolates of Pseudomonas aeruginosa. The biocontrol agents were also found effective in reducing blast and brown spot diseases in rice due to increased accumulation of salicylic acid and pathogenesisrelated peroxidases (Saikia et al. 2006).

\subsubsection{Seedling Dip}

The ShB pathogen is soil-borne, attacks the rice seedlings, and establishes hostpathogen relationship by root entry (Nakkeeran et al. 2005). Seedling root dip treatment of rice prior to transplanting for a period of $2 \mathrm{~h}$ in talc-based formulations of PGPR mixtures at $20 \mathrm{~g} / \mathrm{L}$ reduced ShB incidence effectively (Nandakumar et al. 2001a). Earlier, seedling root dip in a talc-based formulation of $P$. fluorescens before transplantation into main field suppressed ShB disease and improved grain yields (Rabindran and Vidhyasekaran 1996). A novel application method of B. megaterium multiplied in empty fruit bunches (EFB) as carrier was reported. The rice seedlings when treated with bacterial inoculum multiplied in EFB carrier had significantly enhanced plant height, number of roots, and dry matter of root and shoot. The method offered a scope of developing new delivery system and granulation of bioinoculants for effective control of diseases as well as for enhancing grain yields (Al-Taweil et al. 2009). 


\subsubsection{Soil Application}

Soil application of PGPR has also been reported to be an effective method of controlling soil-borne diseases of rice (Rabindran and Vidhyasekaran 1996). For effective suppression of $\mathrm{ShB}$, the population thresholds of the antagonist in soil should be higher than $1 \times 10^{6} \mathrm{cfu} \mathrm{g}^{-1}$ during early stages of infection by $R$. solani (Li et al. 2003). Effective management of ShB is feasible only when the applied bioagents survive, establish, proliferate, and control pathogen populations in soils. A strain of B. licheniformis (CHM1) isolated from rice fields was found to be highly effective in protecting rice seedlings from ShB disease as well as in plant-growth promotion when applied as soil drenching around root zone (Wang et al. 2009). Soil application of peat formulation of $P$. fluorescens (PfALR2) effectively controlled ShB disease under greenhouse and field conditions (Rabindran and Vidhyasekaran 1996). Broadcasting of talc-based formulation mixtures of Pf1 and Pf7 at 30 days of transplanting of rice seedlings reduced $\mathrm{ShB}$ and increased grain yields significantly under field conditions (Nandakumar et al. 2001a). The population levels of PGPR in rice fields are an important factor for effective control of ShB disease. Mixing the potting soil with bacterial suspensions of different $P$. aeruginosa mutants coupled with a soil drench at a concentration of $5 \times 10^{7} \mathrm{cfu}^{-1}$ elicited ISR in rice seedlings to blast and ShB diseases under greenhouse conditions (Vleesschauwer and Hofte 2005).

\subsubsection{Foliar Application}

Survival rates and application efficiencies of PGPR as foliar sprays against plant diseases is generally affected by variations in microclimate. Nutrient concentrations of amino acids, organic acids, and sugars that exude through lenticels, stomata, and hydathodes vary in the phyllosphere (Nakkeeran et al. 2005). The efficacy of PGPR against ShB under greenhouse and field conditions is dependent on time of application. Spraying of $P$. fluorescens at 7 days before pathogen inoculation resulted in effective ShB reduction (59-64\%) over simultaneous application at 7 days after inoculation. Further, grain yields and 1,000 grain weight were also enhanced with the prophylactic sprays (Rajbir Singh and Sinha 2005). Commercial formulations of $P$. fluorescens (Ecomonas and Florezen P) when sprayed three times at 10-day interval after disease initiation under field conditions resulted in ShB control by 14-38\% besides significant increase in grain yields (Vijay Krishna Kumar et al. 2009). Foliar sprays with floating pellet formulation of $B$. megaterium were effective in rice ShB suppression under greenhouse conditions (Wiwattanapatapee et al. 2007). Spraying of antifungal metabolites of Streptomyces spp. (SPM5C-2) at the rate of $500 \mu \mathrm{g} \mathrm{ml}^{-1}$ significantly decreased $\mathrm{ShB}$ and blast disease development by 82 and 76\%, respectively, under greenhouse conditions (Prabavathy et al. 2006). Broadcasting of floating pellets formulation and spraying of water-soluble formulation of $B$. megaterium resulted in effective control of rice $\mathrm{ShB}$ disease under greenhouse and field conditions (Kanjanamaneesathian et al. 2007). 


\subsubsection{Multiple Delivery Systems}

Protection of spermosphere, rhizosphere, and phylloplane from infection courts of plant pathogens through multiple delivery systems of PGPR offers a comprehensive means of plant disease management (Nakkeeran et al. 2005). Talc-based formulations of two P. fluorescens strains (PF1 and PF7) when applied through seed, root, soil, and foliar sprays significantly reduced ShB and pest (leaf-folder) incidence in rice under greenhouse and field conditions. The bacterial mixture performed better than individual strains with a reduction of $62 \%$ of ShB and $47-56 \%$ of leaffolder incidence (Radja Commare et al. 2002). Combined applications of P. fluorescens strains (PF1, FP7, and PB2) as bacterial suspensions or as talc-based formulations through seed, root, foliar, and soil application significantly reduced the ShB incidence $(45 \%)$ under greenhouse and field conditions over their individual applications. Further, a significant increase in yield was obtained with application of mixtures over their individual applications. Fluorescent Pseudomonas application (PF1 and FP7) either as a suspension or talc-based formulation through seed, root, soil, and foliar means effectively reduced rice ShB incidence and promoted plant growth and grain yields (Nandakumar et al. 2001a). Similar results on ShB disease suppression and enhanced yields were reported with peat-based formulations of P. fluorescens (PfALR2) as seed treatment, root treatment, soil application, and foliar spraying. Further, the efficacy of combined application methods was comparable with fungicide treatments (Rabindran and Vidhyasekaran 1996).

\subsubsection{Formulations}

A formulated PGPR should ideally possess high rhizosphere competence, plant growth promotion, ease for large-scale multiplication, wide range of plant disease control, consistent in disease control, and compatible with environment and other rhizobacteria (Nakkeeran et al. 2005). Besides, the bacterial inoculants should be able to tolerate desiccation, heat, oxidizing agents, and UV radiations (Jeyarajan and Nakkeeran 2000). The formulated product should meet the important criteria such as satisfactory shelf life, non-phytotoxic nature, water solubility, ability to withstand environmental fluctuations and compatibility with other agrochemicals. Besides, it should be cost-effective with ready availability of carriers at a cheaper rate and should not impart mammalian toxicity (Nakkeeran et al. 2005; Jeyarajan and Nakkeeran 2000).

The carrier materials used in PGPR formulations are broadly categorized into organic and inorganic ones. The commonly used organic carriers are peat, turf, talc, lignite, kaolinite, pyrophyllite, zeolite, montmorillinite, alginate, press mud, sawdust, and vermiculite (Nakkeeran et al. 2005). In general, PGPR survive longer in carriers with smaller particle sizes than in those with larger particle sizes. Carriers with smaller size will have more surface area that enables increased resistance to desiccation of PGPR through increased coverage of bacterial cells (Dandurand et al. 1994). 
Commonly available PGPR formulations are talc formulations, peat formulations, press mud formulations, vermiculite formulations (Nakkeeran et al. 2005), water-soluble granular formulations, liquid formulations, floating pellet formulations, and formulations with EFB as carriers. Details of different PGPR formulations that exhibited effective control of rice ShB disease under greenhouse or field conditions are given in Table 9.2.

\subsubsection{Shelf life}

Effective disease control by PGPR is possible only when the formulated product delivers a sufficient number of viable cells. So, determining the shelf life and viability of a commercial bio-product is a crucial step. The shelf life of PGPR in the formulated product is dependent on the type of carrier material used. Talc is an excellent carrier material for PGPR with low moisture equilibrium, relative hydrophobicity, reduced moisture absorption, and chemical inertness (Nakkeeran et al. 2005). The population levels of PGPR (fluorescent Pseudomonads) did not decline in talc powder with $20 \%$ xanthan gum after storage for 2 months at $4{ }^{\circ} \mathrm{C}$ (Kloepper and Scroth 1981).

Vermicompost is comparatively a better carrier material than lignite for bioinoculants with high nitrogen, phosphorus, potassium, copper, manganese, and iron besides possessing an ideal $\mathrm{pH}$. The shelf life of vermicompost-based formulations is greater than that of lignite-based ones. The population levels of $B$. megaterium and $P$. fluorescens were very high $\left(7.6 \times 10^{8}\right.$ and $1 \times 10^{8} \mathrm{cfu}^{-1}$ of dry weight, respectively) at the end of 360 days when vermicompost was used as carrier (Gandhi and Saravanakumar 2009).

The shelf life of peat-based formulations depends on the availability of good quality peat. Heat sterilization of peat results in release of toxic substances that are detrimental to bacteria thus affecting their population levels in the formulation (Bashan 1998). The population levels of $P$. fluorescens $\left(2.8 \times 10^{6} \mathrm{cfu} \mathrm{g}^{-1}\right)$ in peatbased formulation was maintained up to 8 months (Vidhyasekaran and Muthamilan 1995), whereas the shelf life of $P$. chlororaphis and B. subtilis were more than 6 months (Kavitha et al. 2003; and Nakkeeran et al. 2004). The use of press mud and vermiculite-based PGPR formulations are also in practice. The viability of Azospirillum spp. in press mud formulation is higher than in lignite (Muthukumarasamy et al. 1997) whereas in vermiculite, its viability is retained up to 10 months (Saleh et al. 2001).

\subsubsection{Root Colonization}

Of different soil microbial populations, bacteria residing in the rhizosphere are the most beneficial. Bacterial communities in the rhizosphere vary in different root 


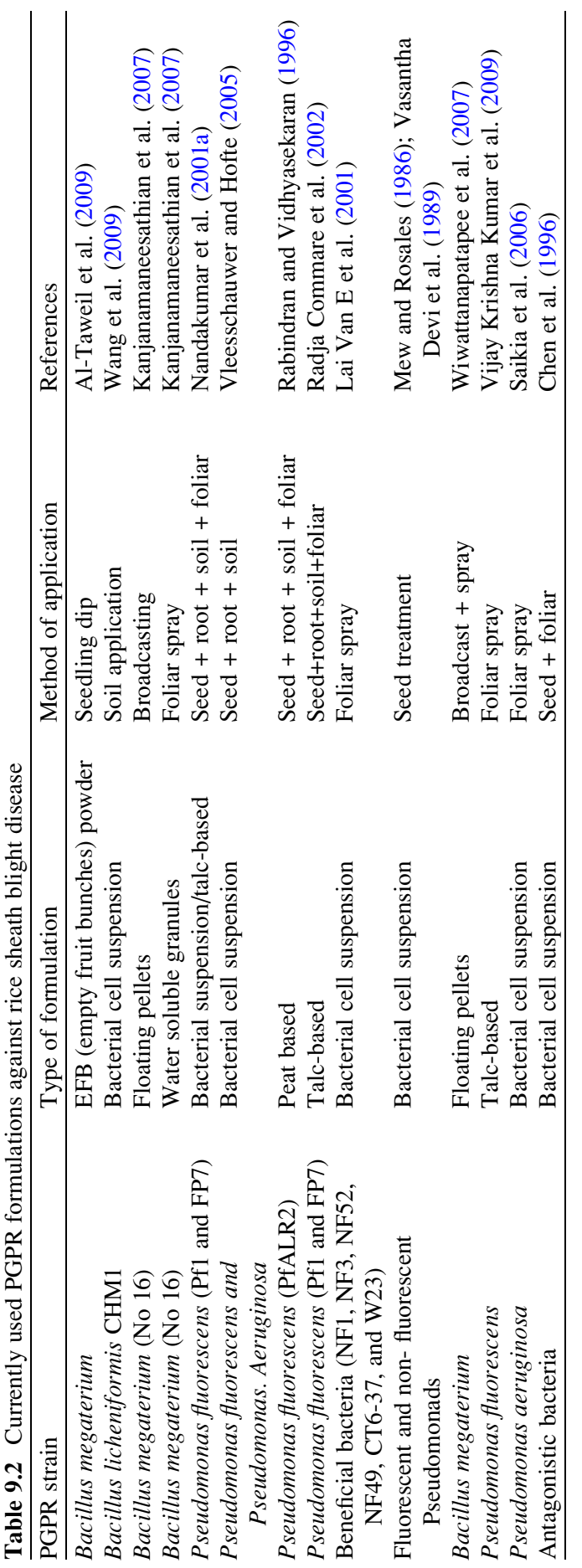


zones and their composition can be altered by changes in root exudate composition (Yang and Crowley 2000). Root exudates of rice plants were found to exert a positive influence on the motility of these bacteria toward plant roots (BacilioJiminez 2003). Earlier studies indicated that the rhizosphere isolates of rice were able to induce IAA production and have phosphate solubilization capacity. Further, these PGPR isolates were found to promote seed germination, root length, plant height, and dry matter production of shoot and roots in rice (Ashrafuzzaman et al. 2009). Application of bio-inoculants was found to enhance rice growth through production of total sugars, reducing sugars, amino nitrogen content, PGP substances in the root exudates, and biological nitrogen fixation. The microbial consortium viz., Azospirillum lipoferum-Az204, B. megaterium var. phosphaticum, and $P$. fluorescens Pf1 when applied to rice improved the colonization potential, sustainability within the inoculants, and enhanced plant growth when compared to their application individually (Raja et al. 2006).

Mirza et al. (2006) reported a nitrogen-fixing, phytohormone-producing Pseudomonas isolate (strain $\mathrm{K} 1$ ) that had a capacity of fixing nitrogen in inoculated rice plants and its efficacy was comparable to non-Pseudomonas nitrogen-fixing PGPR. Use of PGPR also alleviates zinc deficiency in rice plants. Zinc deficiency is a serious problem in rice production (Anon 1993). Inoculation of rice fields with PGPR had a significant positive impact on root length (54\% increase), root weight (74\%), root volume (62\%), root area $(75 \%)$, shoot weight (23\%), panicle emergence index (96\%), and $\mathrm{Zn}$ mobilization efficiency, thereby reducing the cost incurred in the application of chemical $\mathrm{Zn}$ fertilizers (Muhammad et al. 2007). Application of diazotrophs such as Rhizobium leguminosarum bv. trifolii (E11), Rhizobium spp. (IRBG74), and Bradyrhizobium sp. IRBG271 in lowland rice fields enhanced N, P, and K uptake by 10-28\% due to rhizobial inoculation. In addition, the uptake of $\mathrm{Fe}$ was enhanced by $15-64 \%$. Further, the growth promotion in rice was due to changes in growth physiology or root morphology rather than biological nitrogen fixation (BNF) (Biswas et al. 2000).

\subsection{Sheath Blight Management}

In rice, PGPR offer a promising means of controlling plant diseases besides contributing to the plant resistance, growth, and grain yields (Mew and Rosales 1992). Of different PGPR, fluorescent Pseudomonads and Bacillus spp. group of bacteria are widely used against ShB. Their application promotes plant growth by direct and indirect mechanisms. Direct growth promotion is due to production of phytohormones, solubilization of phosphates, increased uptake of iron through production of siderophores, and volatile metabolites. Indirect way of plant growth promotion is due to mechanisms of antibiosis, competition for space and nutrients, parasitism or lysis of pathogen hyphae, inhibition of pathogen-produced enzymes or toxins, and through induced systemic resistance (ISR). The ISR in rice against $\mathrm{ShB}$ is either due to enhanced chitinase or peroxidase activity (Nandakumar et al. 
2001b). However, no correlation was observed between chitinase production and ShB suppression (Thara and Gnanamanickam 1994). Strains of $P$. fluorescens were found to produce siderophores, volatile metabolites, extracellular secretions, and antibiotics that were inhibitory to $\mathrm{ShB}$ pathogen. Further, the strains reduced germination and caused lysis of sclerotia (Kazempour 2004). Rhizosphere isolates of $P$. fluorescens produced $\beta$-1,3-glucanase, salicylic acid, and HCN, and a significant relationship was observed between antagonism of the bacterium and the production of these substances (Nagarajkumar et al. 2004).

Bacillus spp. are endospore-producing gram-positive bacteria, and some strains have been used in biocontrol of rice diseases. Strains of B. subtilis and B. megaterium exhibit inhibition of Rhizoctonia solani (Luo et al. 2005). The fermented product of Bacillus (Drt-11) is highly inhibitory to the sclerotial germination, hyphal growth, and colony diameter besides enhancing rice seedling growth (Chen and Hui 2006). Strains of Bacillus produce a thermo and proteinase - stable antagonistic substance (P1) that is effective against rice ShB and blast pathogens (He et al. 2002). The B. subtilis (AUBS1) strain produces phenylalanine ammonialyase (PAL), peroxidase (PO), and certain pathogenesis-related (PR) proteins in rice leaves when applied against $\mathrm{ShB}$ disease. Accumulation of thaumatin-like proteins, glucanases, and chitinases are the other important substances in plants against ShB by these bioagents (Jayaraj et al. 2004). The other promising bacteria against rice ShB include Streptomyces spp. and Serratia marcescens. The antifungal metabolites of Streptomyces spp. (PM5, SPM5C-1, and SPM5C-2) were highly effective against mycelial growth of rice ShB and blast pathogens under in vitro conditions. Greenhouse studies revealed that spraying of the strain SPM5C-2 at $500 \mu \mathrm{g} \mathrm{ml}^{-1}$ significantly reduced ShB and blast diseases by 82 and $76 \%$, respectively (Prabavathy et al. 2006). Culture filtrates of S. marcescens exhibited enhanced reduction of sclerotial viability of ShB pathogen, when applied with reduced doses of fungicides such as flutolanil, pencycuron, and validamycin (Someya et al. 2005).

In order to identify a potential biocontrol agent, researchers have been spending their time on several microbes in areas of isolation, identification, and purification which is routine. This is a laborious process demanding efforts of time and manhours. Here, we have provided our own selection of a potential microbial inoculant against rice $\mathrm{ShB}$.

\subsubsection{Screening of Different PGPR Against ShB Pathogen and Seedling Growth Promotion Under Laboratory Conditions}

Seventy PGPR strains that belong to Bacillus, Paenibacillus, Brevibacillus, and Arthrobacter were selected from the bacterial culture collection of the Phytopathology Laboratory of Auburn University. These PGPR strains were found to be highly effective in inducing growth-promoting effects in various crops. These strains were screened against rice $\mathrm{ShB}$ pathogen, $\mathrm{ShB}$ lesion spread and in promoting rice 
Table 9.3 Benefits and use rates of Integral in different crops

\begin{tabular}{|c|c|c|c|}
\hline Crop & $\begin{array}{l}\text { Method of } \\
\text { application }\end{array}$ & Rates of application & Target pathogens \\
\hline Peanut & In-furrow & $0.1-1.2 \mathrm{fl} \mathrm{oz} /$ acre & $\begin{array}{l}\text { Rhizoctonia, Fusarium, } \\
\text { Aspergillus }\end{array}$ \\
\hline $\begin{array}{l}\text { Cotton, vegetables, soybean } \\
\text { corn }\end{array}$ & In-furrow & $0.1-1.2 \mathrm{fl} \mathrm{oz} /$ acre & Rhizoctonia, Fusarium \\
\hline $\begin{array}{l}\text { Non-bearing plants (Cherry) } \\
\text { in greenhouses }\end{array}$ & Soil mix & $1.3-13 \mathrm{fl} \mathrm{oz} /$ acre & Fusarium, Rhizoctonia \\
\hline Cotton & Seed & $0.6-2.4 \mathrm{fl} \mathrm{oz} / 100 \mathrm{lb}$ seed & Fusarium Rhizoctonia \\
\hline Soybeans & Seed & $0.13 \mathrm{fl} \mathrm{oz} / 100 \mathrm{lb}$ seed & Fusarium Rhizoctonia \\
\hline $\begin{array}{l}\text { Green beans, snap beans, } \\
\text { lima beans, kidney } \\
\text { beans, navy beans, } \\
\text { pinto beans, wax } \\
\text { beans, pole beans, } \\
\text { garden beans, peas, } \\
\text { field beans }\end{array}$ & Seed & $0.6-2.4 \mathrm{fl} \mathrm{oz} / 100 \mathrm{lb}$ seed & Fusarium Rhizoctonia \\
\hline Alfalfa, forage, turf & Seed & $0.2-12 \mathrm{fl} \mathrm{oz} / 100 \mathrm{lb}$ seed & Fusarium Rhizoctonia \\
\hline Wheat, barley & Seed & $0.1-0.6 \mathrm{fl} \mathrm{oz} / 100 \mathrm{lb}$ seed & Fusarium Rhizoctonia \\
\hline Field corn, sweet corn & Seed & $0.6-2.4 \mathrm{fl} \mathrm{oz} / 100 \mathrm{lb}$ seed & Fusarium \\
\hline Canola & Seed & $1.6-3.8 \mathrm{fl} \mathrm{oz} / 100 \mathrm{lb}$ seed & Fusarium Rhizoctonia \\
\hline
\end{tabular}

seedling growth under laboratory conditions. The mycelial growth inhibition of $R$. solani was as high as $83 \%$ with $B$. subtilis MBI 600 , compared to the control. Only four strains completely inhibited the germination of sclerotia. The ShB lesion spread was determined by highest relative lesion height method (HRLH) and for effective strain (B. subtilis MBI 600) was found to be only 2.9 as against control (100). Highest seedling vigor of 13,600 was recorded in comparison to that of control $(4,867)$ on 10 -day-old seedlings. The PGPR strain, B. subtilis MBI 600 was found to be highly effective in all the screening assays and was selected for further studies.

To further test the efficacy of $B$. subtilis MBI 600 , the strain was produced in a commercial proprietary liquid formulation by Becker Underwood, Ames, Iowa, USA. The formulated strain MBI 600 has a proprietary trade name as Integral ${ }^{\circledR}$. The product is stored at room temperatures prior to use. The minimum concentration of Integral in liquid formulation is $2.2 \times 10^{10} \mathrm{cfu} \mathrm{ml}^{-1}$. The details of different application methods of Integral are shown in Table 9.3.

\subsubsection{Efficacy of Integral}

To assess the biocontrol suppression of ShB by using antagonistic bacteria and their combination with fungicide under field conditions for a long time, antagonistic bacteria and fungicide used to control ShB must be evaluated for durability effect.

Improved plant growth and health by PGPR is either due to direct mechanisms such as improvement in plant uptake through solubilization of mineral phosphates 
and other nutrients (De Freitas et al. 1997; Gaur 1990), nitrogen fixation (Boddey and Dobereiner 1995), and phytohormone production such as indole 3-acetic acid, gibberellic acid, cytokinins, and ethylene (Arshad and Frankenberger 1993; Glick 1995). Indirect growth promotion is through biological control of plant pathogens by producing siderophores (Scher and Baker 1982), antibiotics (Shanahan et al. 1992), hydrogen cyanide (Flaishman et al. 1996), lytic enzymes, and competition for nutrients and space.

\subsubsection{In-Vitro Inhibition of ShB Pathogen}

The $B$. subtilis MBI 600 strain of Integral was further characterized for determining its mode of action against ShB pathogen. The PGPR strain was isolated from the formulation on TSA and confirmation of its purity was carried out using 16s rDNA sequence homology and by measuring the 16s rDNA sequence with 1,409 base pairs of the isolate. The BLAST analysis of the sequencing results confirmed $100 \%$ similarity with B. subtilis. The MBI 600 strain was highly effective against the ShB pathogen, $R$. solani and repeatedly shown significant results in inhibiting mycelial growth (Fig. 9.2) and germination of sclerotia (Fig. 9.3) under in-vitro conditions. A strong zone of inhibition $(3 \mathrm{~mm})$ between mycelial growth of pathogen and bacterium was observed. Inhibition of sclerotial germination was about $98 \%$ at a concentration of $2.2 \times 10^{9} \mathrm{cfu} \mathrm{ml}^{-1}$ whereas at a concentration of $2.2 \times 10^{8} \mathrm{cfu} \mathrm{ml}^{-1}$, the inhibition was $37 \%$. Integral was not effective in inhibiting sclerotial germination at concentrations of $2.2 \times 10^{6}$ and $2.2 \times 10^{7} \mathrm{cfu} \mathrm{ml}^{-1}$. Highest inhibition of sclerotial growth was obtained at a concentration of $2.2 \times 10^{9} \mathrm{cfu} \mathrm{ml}^{-1}(79 \%)$, followed by at $2.2 \times 10^{8} \mathrm{cfu} \mathrm{ml}^{-1}(72 \%)$. Integral was also effective at lower concentrations with sclerotial growth inhibitions ranging from 29 to $60 \%$ (Table 9.4).

Efficacy of Integral was evaluated in reducing ShB lesions on rice leaves under in vitro conditions by detached leaf piece assay. Integral concentrations of

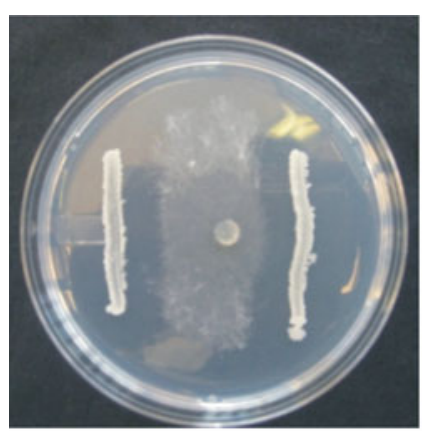

Challenged with Integral

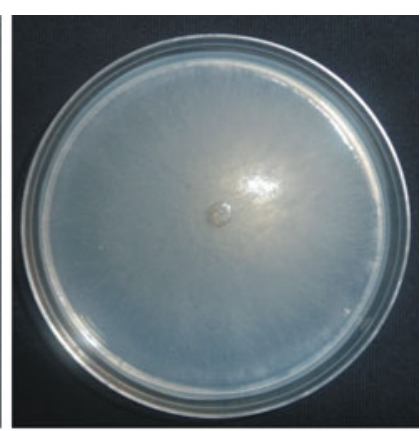

Without Integral

Fig. 9.2 Inhibition of mycelial growth of Rhizoctonia solani challenged with Integral 


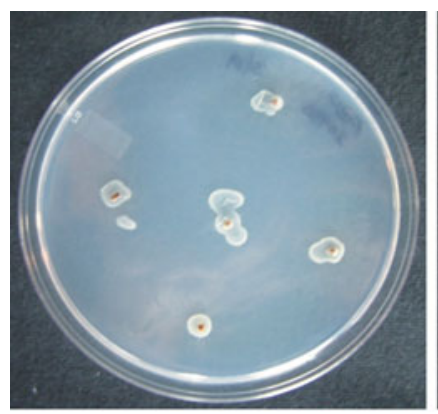

Challenged with Integral

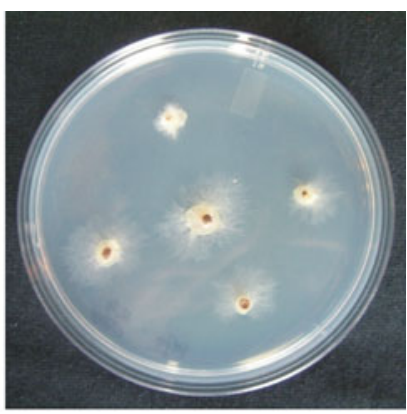

Without Integral

Fig. 9.3 Inhibition of sclerotial germination of Rhizoctonia solani by Integral

Table 9.4 Efficacy of Integral on sclerotial germination and sheath blight lesion symptoms of rice

\begin{tabular}{llll}
\hline Concentration $^{1}$ & $\begin{array}{l}\text { \% Inhibition of } \\
\text { sclerotial germination }\end{array}$ & $\begin{array}{l}\text { \% Inhibition of sclerotial } \\
\text { growth compared to control }^{3}\end{array}$ & $\begin{array}{l}\text { ShB lesion } \\
\text { spread }^{4}\end{array}$ \\
\hline $2.2 \times 10^{6} \mathrm{CFU} / \mathrm{ml}$ & $0^{\mathrm{c}}$ & $28.5^{\mathrm{d}}$ & $92.6^{\mathrm{b}}$ \\
$2.2 \times 10^{7} \mathrm{CFU} / \mathrm{ml}$ & $0^{\mathrm{c}}$ & $59.5^{\mathrm{c}}$ & $71.6^{\mathrm{c}}$ \\
$2.2 \times 10^{8} \mathrm{CFU} / \mathrm{ml}$ & $36.7^{\mathrm{b}}$ & $71.8^{\mathrm{b}}$ & $22.7^{\mathrm{d}}$ \\
$2.2 \times 10^{9} \mathrm{CFU} / \mathrm{ml}$ & $97.7^{\mathrm{a}}$ & $78.8^{\mathrm{a}}$ & $4.7^{\mathrm{e}}$ \\
Control & $0^{\mathrm{c}}$ & - & $99.2^{\mathrm{a}}$ \\
\hline
\end{tabular}

Means followed by a common letter in the columns are not significantly different at $p \leq 0.05$

${ }^{1}$ Integral applied at these concentrations to test on sclerotial germination, growth of mycelia, and suppression of ShB lesions

${ }^{2}$ Sclerotial germination was recorded at 3 days after incubation

${ }^{3}$ Sclerotial growth was recorded at 5 days after incubation and

${ }^{4} \mathrm{ShB}$ lesion spread was recorded by Highest Relative Lesion Height method at 7 days after inoculation

$2.2 \times 10^{6}$ through $2.2 \times 10^{9} \mathrm{cfu} \mathrm{ml}^{-1}$ were sprayed onto rice leaf pieces $(8 \mathrm{~cm})$ separately. Later the leaves were inoculated with 1 -week-old sclerotia of $R$. solani at the centre and leaves were incubated in Petri dishes containing moistened filter papers. ShB lesion length around sclerotium was recorded after 5 days and disease severity was assessed by highest relative lesion height (HRLH) method. As shown in Fig. 9.4, Integral at $2.2 \times 10^{9} \mathrm{cfu} \mathrm{ml}^{-1}$ significantly reduced $\mathrm{ShB}$ lesion spread on detached rice leaves (4.7) (Table 9.4). At other concentrations, the lesion spread ranged from 23 to 93 as against untreated control (100).

Integral was tested positive for production of siderophores. However, production of IAA, HCN, cellulase, chitinase, and phosphate solubilizing capacity when tested were negative. Siderophores are low-molecular-weight iron-chelating agents produced by PGPR that can create iron nutrient competition in soils to plant pathogens. Since the element iron is present in low quantities in soils, siderophore production is a strategy by the PGPR to compete with soil-borne plant pathogens. 
Fig. 9.4 Suppression of sheath blight lesions in a detached leaf assay with Integral

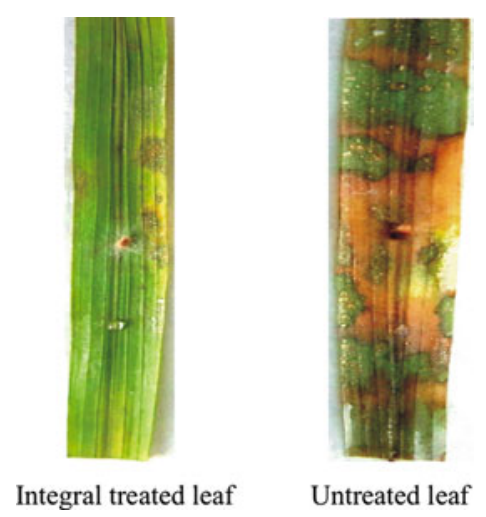

\subsubsection{Rice Plant Growth Promotion}

Seed treatment with Integral was highly effective in promoting rice seedling development both under laboratory and greenhouse conditions. Under in vitro conditions, significantly higher root and shoot lengths were observed with Integral over untreated control. Increase in root and shoot lengths was noticed with an increase in Integral concentration from $2.2 \times 10^{6} \mathrm{cfu} \mathrm{ml}^{-1}$ to $2.2 \times 10^{9} \mathrm{cfu} \mathrm{ml}^{-1}$. As shown in Fig. 9.5, highest root and shoot lengths (47.5 and $39.1 \mathrm{~mm}$, respectively) were recorded at a concentration of $2.2 \times 10^{9} \mathrm{cfu} \mathrm{ml}^{-1}$ as against control (14.3 and $7.6 \mathrm{~mm}$ of root and shoot lengths respectively).

Under greenhouse conditions, seed treatment with Integral significantly improved rice seed germination, seedling emergence, and plant growth. The percent germination of seeds sown in $15 \mathrm{~cm}$ pots filled with field soil was highest at a concentration of $2.2 \times 10^{9} \mathrm{cfu} \mathrm{ml}^{-1}(88.9 \%)$ as against untreated control $(61.1 \%)$ at 7 days after sowing (DAS). Integral application significantly improved root and shoot lengths at 15 DAS. Highest root length and shoot length were recorded at a concentration of $2.2 \times 10^{9} \mathrm{cfu} \mathrm{ml}^{-1}$ (166 and $335 \mathrm{~mm}$ respectively) as against untreated control (73 and $222 \mathrm{~mm}$ respectively) (Fig. 9.6).

\subsubsection{Chemical Compatibility}

Currently, $\mathrm{ShB}$ disease management strategy is through use of systemic fungicides and also with certain non-systemic fungicides (Pal et al. 2005). Pathogen resistance to these systemic fungicides is of concern, thus demanding integration of PGPR in IDM. Since, host plant resistance to ShB range only from very susceptible to moderately susceptible levels in rice (Groth and Bond 2007), use of chemical fungicides has become a necessary component for an effective ShB management. For effective functioning of PGPR under the ambit of IDM, their compatibility with commonly used fungicides and insecticides in rice is also mandatory (Mew et al. 2004). 
Fig. 9.5 Effect of Integral on rice seed development

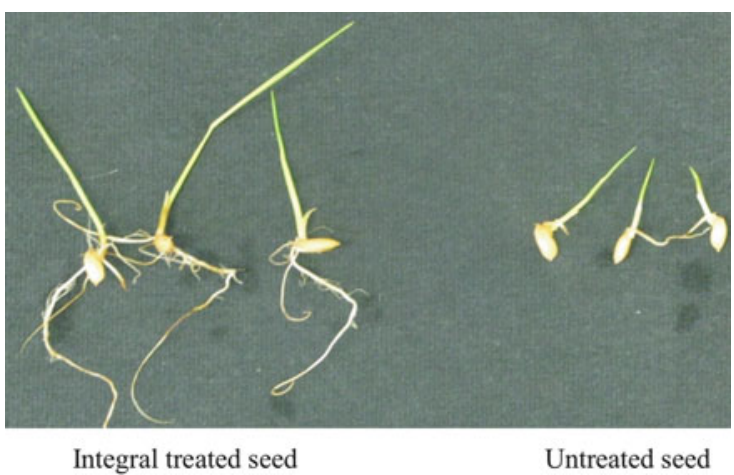

Fig. 9.6 Efficacy of Integral on rice seedling growth

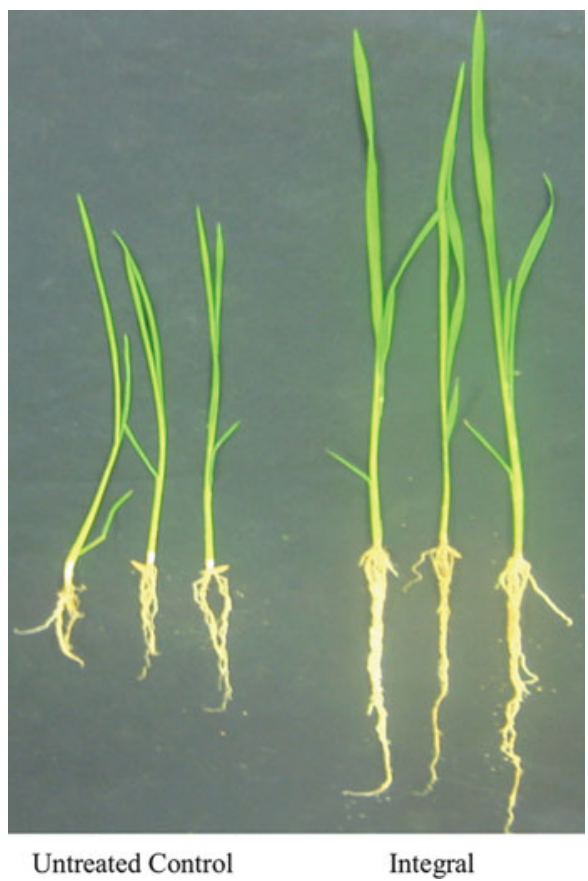

Combined applications of PGPR with chemical fungicides are an important IDM package against ShB. Of different PGPR, Pseudomonads and Bacillus spp. were found to be very effective as a supplement in IDM. Greenhouse and field studies against rice $\mathrm{ShB}$ with different $\mathrm{PGPR}$ isolated from farmyard manure, rice seed, phyllosphere, and rhizosphere proved that three bacteria, P. fluorescens (PF-9), Bacillus sp. (B-44), and a chitinolytic bacterium (Chb-1) are compatible with carbendazim at 500 and 1,000 ppm concentrations. Of these, PF-9 was most effective in reducing $\mathrm{ShB}$ severity either alone or in combination with one spray of $0.1 \%$ carbendazim, followed by combination of PF-9 and B-44 (Laha and 
Venkataraman 2001). The B. subtilis (Bs-916) when applied along with jinggangmycin was found to colonize the root system effectively. Further, the population density of BS-916 was maintained in its presence without any further decline (Chen et al. 2003).

In order to use Integral in ShB management, it has to be compatible with existing agronomic practices and commonly used chemical fungicides in rice production systems. In our ongoing research, we have attempted to study our classical product Integral according to the assays described by Shanmugam and Narayanasamy (2009) under in vitro conditions. Briefly, in this assay, a loop full of MBI 600 strain onto Nutrient Agar (NA) plates amended with various concentrations (100-1,000 ppm) of fungicides such as propiconazole, validamycin, benomyl, carbendazim, tricyclazole, mancozeb, azoxystrobin, and hexaconazole. Plates were later incubated at room temperature for $48 \mathrm{~h}$ and growth of bacterium was monitored. Further compatibility studies with azoxystrobin and carbendazim were carried out according to Omar et al. (2006) wherein $100 \mu \mathrm{L}$ of bacterial inoculum was added to $250 \mathrm{ml}$ yeast peptone glucose (YPG) liquid medium amended with fungicides at concentrations at 200 and 400 ppm and incubated on a shaker, growth of bacterium was enumerated on NA after serial dilution.

Integral exhibited good tolerance to hexaconazole, propiconazole, and validamycin, moderately to tricyclazole and slightly to benomyl and mancozeb at $1,000 \mathrm{ppm}$. It was highly compatible with carbendazim and azoxystrobin up to $400 \mathrm{ppm}$ whereas complete inhibition was obtained with these fungicides at $800 \mathrm{ppm}$ (Table 9.5). Compatibility to azoxystrobin and carbendazim showed up to $400 \mathrm{ppm}$, and good growth of Integral was in carbendazim- and azoxystrobinamended medium (Figs. 9.7 and 9.8).

\subsubsection{Efficacy of PGPR Against ShB Under Greenhouse and Field Conditions}

The time of application of PGPR has significant influence in the management of ShB disease. Ren et al. (2006) reported that the optimum time of application

Table 9.5 Compatibility of Integral with commonly used fungicides

\begin{tabular}{lllllll}
\hline Fungicides & \multicolumn{7}{l}{ Fungicide concentrations $(\mathrm{ppm})^{\mathrm{a}}$} \\
\cline { 2 - 7 } & 100 & 200 & 400 & 600 & 800 & 1,000 \\
\hline Propiconazole & +++ & +++ & +++ & +++ & +++ & +++ \\
Validamycin & +++ & +++ & +++ & +++ & +++ & +++ \\
Benomyl & +++ & +++ & +++ & +++ & ++ & + \\
Carbendazim & +++ & +++ & +++ & + & -- & -- \\
Tricyclazole & +++ & +++ & +++ & +++ & +++ & ++ \\
Mancozeb & +++ & +++ & +++ & ++ & + & + \\
Azoxystrobin & +++ & +++ & +++ & + & -- & -- \\
Hexaconazole & +++ & +++ & +++ & +++ & +++ & +++ \\
\hline
\end{tabular}

${ }^{a}$ Growth of Integral in NA amended with fungicides: $+++=$ Good; $++=$ Moderate; $+=$ Slight; $--=$ No growth 


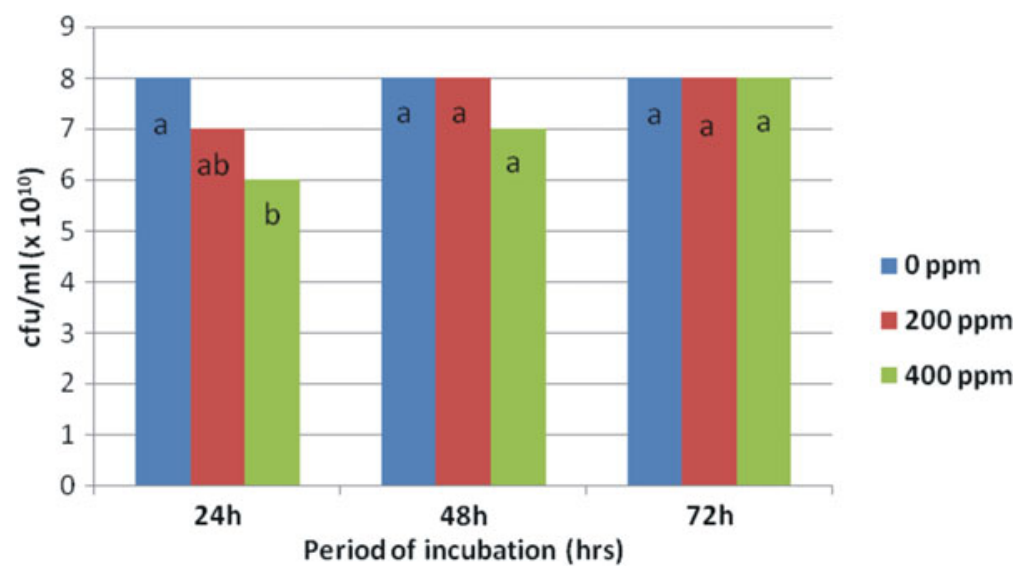

Fig. 9.7 Compatibility of Integral with Carbendazim. Values are means of five replications. Means followed by a common letter are not significantly different at $p \leq 0.05$

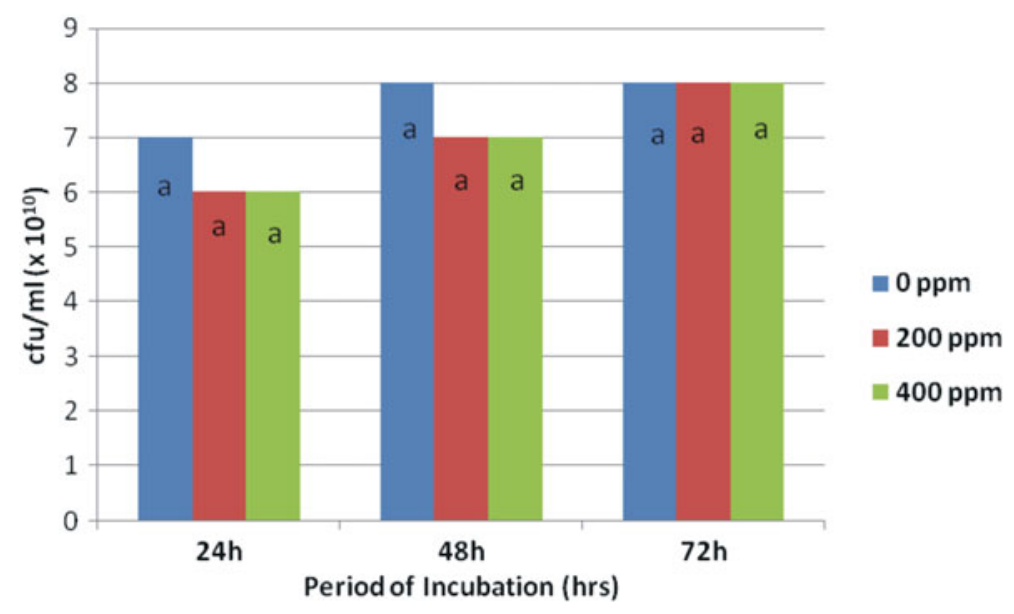

Fig. 9.8 Compatibility of Integral with Azoxystrobin. Values are means of five replications. Means followed by a common letter are not significantly different at $p \leq 0.05$

of PGPR against ShB under field conditions was during the first day of inoculation of $R$. solani. Reduction in ShB severity under field conditions by PGPR is also dependent on the bacterial concentration. It is interesting to note that the PGPR when applied as consortia and in conjunction with other fungal antagonists offered synergistic effect over their individual applications in ShB disease reduction. Talcbased formulations of two P. fluorescens strains (PF1 and PF7), when applied as seed, soil, and root dip treatments and foliar sprays, significantly reduced ShB and leaf-folder incidence under greenhouse and field conditions. The PGPR mixture proved to be more effective over their individual applications (Radja Commare et al. 2002). Combined use of $P$. fluorescens and Trichoderma viride was effective 
in rice ShB reduction and enhanced seedling growth (Mathivanan et al. 2006). Bacillus spp. exhibited synergistic effect when used in conjunction with $T$. viride (Das et al. 1998) and Gliocladium virens (Sarmah 1999) against ShB. The fermented product of Bacillus strain Drt-11 when applied in combination with biofungicide, Jinggangmeisu WP (20\%) proved to be more effective against ShB over their individual applications (Chen and Hui 2006).

Our own studies with Integral under greenhouse and field studies effectively reduced ShB incidence in rice. In a typical greenhouse assay, Integral was evaluated at concentrations of $2.2 \times 10^{6}$ to $2.2 \times 10^{9} \mathrm{cfu} \mathrm{ml}^{-1}$ as seed treatment (ST), seedling root dip (SD), and foliar sprays (FS). Seed treatment with Integral at concentrations of $2.2 \times 10^{8}$ and $2.2 \times 10^{9} \mathrm{cfu} \mathrm{ml}^{-1}$ significantly improved percent germination over untreated control. Further, the root and shoot lengths were significantly improved (12.2 and $40.7 \mathrm{~cm}$ respectively) at $2.2 \times 10^{9} \mathrm{cfu} \mathrm{ml}^{-1}$ as against untreated control ( 7.9 and $33.8 \mathrm{~cm}$ respectively) at 25 DAS. Significant reduction in ShB severity (9.2 vs. 24.1 in untreated control) (Fig. 9.9), increase in plant height (73.2 vs. $62.7 \mathrm{~cm}$ in untreated control) and number of tillers/plant (11.9 vs. 8.0 in untreated control) was obtained when Integral was applied at $2.2 \times 10^{9} \mathrm{cfu} \mathrm{ml}^{-1}$ as seed treatment (ST) + seedling root dip (SD) + foliar sprays (FS).

Our field studies at Andhra Pradesh Rice Research Institute (APRRI), India during 2009 indicated significant improvement in root and shoot lengths or rice seedlings in nursery with Integral seed treatment at $2.2 \times 10^{8}$ and $2.2 \times$ $10^{9} \mathrm{cfu} \mathrm{ml}^{-1}$ over untreated control. On a transplanted crop, Integral application as $\mathrm{ST}+\mathrm{SD}+\mathrm{FS}$ at $2.2 \times 10^{9} \mathrm{cfu} \mathrm{ml}^{-1}$ significantly reduced sheath blight severity (19.2 vs. 69.7 in control) and percent diseased tillers (25.1 vs. 99.4 in control)

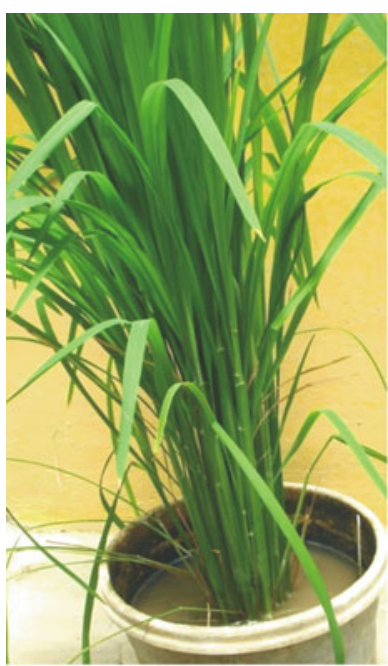

Seedlings treated with Integral

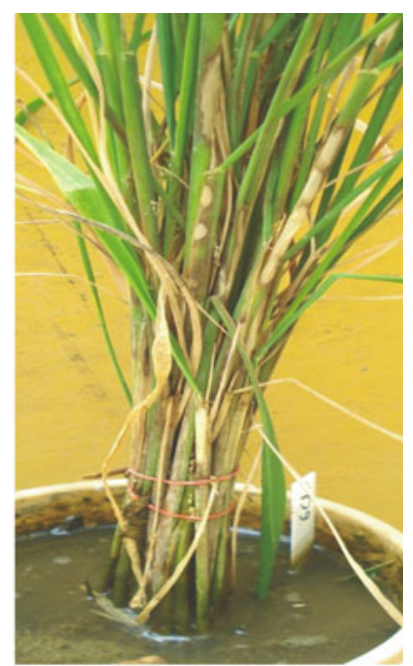

Seedling without Integral

Fig. 9.9 Suppression of sheath blight severity with Integral under greenhouse conditions 


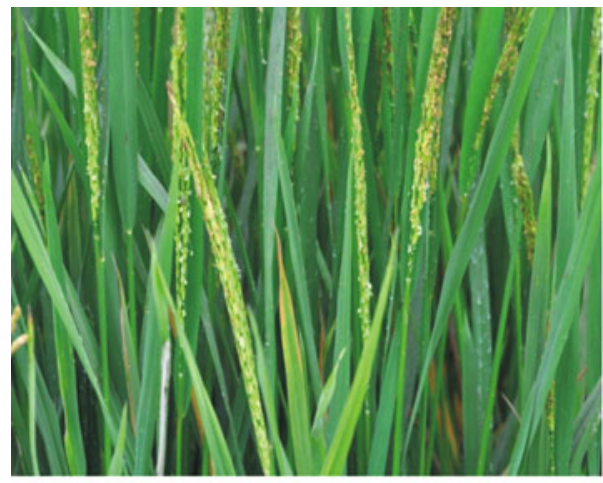

Integral treated plot

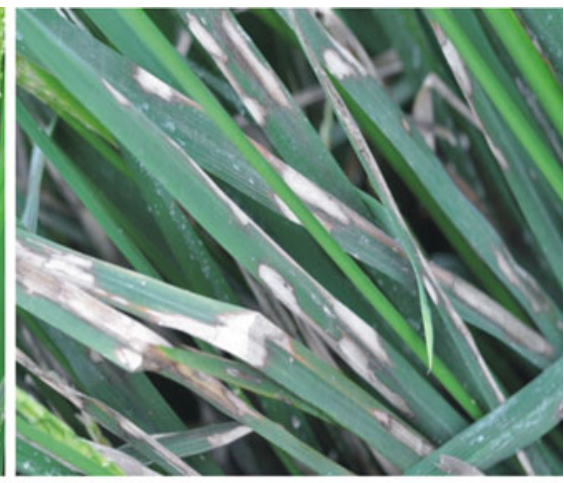

Untreated Control

Fig. 9.10 Sheath blight severity under field conditions

(Fig. 9.10). Plant height (98.1 vs. $78.5 \mathrm{~cm}$ in control), tillers/plant (12.8 vs. 10.0 in control), and grain yields were maximum with Integral application at $2.2 \times$ $10^{9} \mathrm{cfu} \mathrm{ml}^{-1}$ as ST $+\mathrm{SD}+\mathrm{FS}$. Integral was also effective in reducing ShB severity and promoting growth and grain yields at a concentration of $2.2 \times 10^{8} \mathrm{cfu} \mathrm{ml}^{-1}$.

\subsection{Conclusions}

As shown by the examples discussed in this chapter, PGPR have good potential in the management of rice ShB. It is generally believed that the field efficacy of a particular PGPR strain is dependent on its root colonization capacity. According to this reasoning, rhizosphere competence of a PGPR strain is a desirable trait for its effective root colonization and subsequent disease control. Earlier reports indicated that diversity of PGPR in rice rhizosphere is changing according to soil salinity. With increase in soil salinity, the population levels of Pseudomonas spp. decreased. In non-saline sites of rice rhizosphere, fluorescent Pseudomonads are the dominant species whereas in saline sites, these were replaced by salt tolerant species such as $P$. alcaligens and $P$. pseudoalcaligens. Further, organic farming was found to significantly enhance the diversity of PGPR populations in saline soils (Rangarajan et al. 2002).

It should be noted that although rhizosphere competence is considered important for effective PGPR biocontrol agents, there could be exceptions. For example, if a particular PGPR-based product is applied as a foliar spray, rhizosphere colonization would not be strictly required. For example, with the product Intergral, which was highly effective in biocontrol of ShB in field trials in India, one application method was a foliar spray. To date, there are no published studies examining possible rhizosphere competence or root colonization on rice by the PGPR strain contained in Integral (B. subtilis strain MBI600). 
Several biotic and abiotic factors also have significant impact on the field consistency of a formulated PGPR strain in rice ShB management. Since grampositive bacilli produce endospores that can withstand desiccation and have a long shelf life, they are considered to be ideal candidates for commercial use against $\mathrm{ShB}$. Fungicidal compatibility of selected PGPR strain is another important factor that determines the efficacy of PGPR under IDM. Consistent efforts are therefore needed to select PGPR strain with all the desirable traits that contribute to effective rice $\mathrm{ShB}$ management.

Although several advantages have been reported with the use of microbial inoculants in rice, variability in effectiveness of field performance remains a constraint. To overcome this, comprehensive basic research is essential in the areas of selection of microbial agents that focus on identifying strains that occupy the same ecological niche with that of pathogens such as roots, the phylloplane, and vascular systems. Application of novel techniques such as PCR, RFLP, and RAPD for rapid identification of bacterial strains with desirable traits like biocontrol and growth-promoting mechanisms are therefore necessary. Integrating these basic research concepts with studies on greenhouse and field studies are therefore essential before devising IDM approaches for ShB management in rice. The PGPR that are identified in these respects should be maintained as important genetic resource, which will be useful for future studies that form an alternate to the presently available chemical control of ShB.

Acknowledgments The primary author is thankful to the authorities of Acharya N G Ranga Agricultural University, India for granting sabbatical to pursue his Ph.D. program at Auburn University, USA. The authors are thankful to the Associate Director of Research, A. P. Rice Research Institute, India for extending help in carrying out greenhouse and field studies. The support of Rice Research Station, LSU AgCenter, USA in providing the seed material and pathogen for our investigations, and of Becker Underwood, USA in providing the Integral formulation is highly appreciated.

\section{References}

Al-Taweil HI, Osman MB, Hamid AA, Wan Yusoff WM (2009) Development of microbial inoculants and the impact of soil application on rice seedling growth. Am J Agric Biol Sci 4(1):79-82

Anonymous (1993) International Rice Research Institute. 1993-1995. IRRI rice almanac, IRRI, Los Banos, Philippines

Arndt W, Kolle C, Buchenauer H (1998) Effectiveness of fluorescent pseudomonads on cucumber and tomato plants under practical conditions and preliminary studies on the mode of action of the antagonists. Zeit Pflanzen Pflanz 105:198-215

Arshad M, Frankenberger WT Jr (1993) Microbial production of plant growth regulators. In: Metting BF Jr (ed) Soil microbial ecology. Marcel and Dekker Inc., New York, pp 307-347

Ashrafuzzaman M, Hossen FA, Razi Ismail M, Md AH, Zahurul Islam M, Shahidullan SM, Meon S (2009) Efficiency of plant growth-promoting rhizobacteria (PGPR) for the enhancement of rice growth. Afr J Biotechnol 8(7):1247-1252 
Babalola OO, Osir EO, Sanni AI, Odhiambo GD, Bulimo WD (2003) Amplification of 1-aminocyclopropane-1-carboxylic (ACC) deaminase from plant growth promoting rhizobacteria in Striga-infested soil. Afr J Biotechnol 2:157-160

Bacilio-Jiminez M (2003) Chemical characterization of root exudates from rice (Oryza sativa) and their effects on the chemotactic response of endophytic bacteria. Plant Soil 249: 271-277

Baldani JI, Baldani VLD, Seldin L, Dobereiner J (1986) Characterization of Herbaspirillum seropedicae gen. nov., sp. nov., a root-associated nitrogen fixing bacterium. Int J Syst Bacteriol 36(1):86-93

Bally R, Thomas-Bauzon D, Heulin T, Balandreau J, Richard C, De Lay J (1983) Determination of the most frequent $\mathrm{N}_{2}$-fixing bacteria in a rice rhizosphere. Can J Microbiol 29:881-887

Bangura N, John VT (1991) Incidence, distribution and severity of bacterial diseases on rice in West Africa. Int J Pest Manag 37(2):113-117

Bashan Y (1998) Inoculants of plant growth-promoting rhizobacteria for use in agriculture. Biotechnol Adv 16:729-770

Bertand H, Nalin R, Bally R, Cleyet-Marel JC (2001) Isolation and identification of the most efficient plant growth-promoting bacteria associated with canola (Brassica napa). Biol Fert Soils 33:152-156

Bilal R, Rasul G, Qureshi JA, Malik KA (1990) Characterization of Azospirillum and related diazotrophs associated with roots of plants growing in saline soils. World J Microbiol Biotechnol 6:46-52

Biswas JC, Ladha JK, Dazzo FB (2000) Rhizobia inoculation improves nutrient uptake and growth of lowland rice. Soil Sci Soc Am J 64:1644-1650

Boddey RM, Dobereiner J (1995) Nitrogen fixation associated with grasses and cereals: recent progress and perspectives for the future. Fert Res 42:241-250

Boddey RM, Baldani VLD, Baldani JI, Dobereiner J (1986) Effect of inoculation of Azospirillum spp. on nitrogen accumulation by field grown wheat. Plant Soil 95:109-121

Bonaterra A, Ruz L, Badosa E, Pinochet J, Montesinos E (2003) Growth promotion of Prunus root stocks by root treatment with specific bacterial strains. Plant Soil 255:555-569

Bowen GD, Rovira AD (1999) The rhizosphere and its management to improve plant growth. Adv Agron 66:1-102

Cezon R, Manero FJ, Gutierrez PA, Ramos B, Garica JAL (2003) Effects of two plant growthpromoting rhizobacteria on the germination and growth of pepper seedlings (Capsicum annum) cv. Roxy. Arch Agr Soil Sci 49:593-603

Chen M, Hui KX (2006) The research exploration to the effect of controlling rice sheath blight with Bacillus spp. Drt-11. Southwest China J Agric Sci 19(1):53-57

Chen ZY, Yin SZ, Lu F, Li ZP (1996) Screening and utilization of antagonistic bacteria for rice sheath blight control. In: Tang WH, Cook RJ, Rovira A (eds) Advances in biological control of plant diseases. China Agricultural University Press, Beijing, pp 1-5

Chen Z, YongFeng Liu, Fan Lu (2003) Co-operative action between jinggangmycin and Bacillus subtilis Bs-916 against rice sheath blight. Acta Phytop Sin 30(4):429-434

Dandurand LM, Morra MJ, Chaverra MH, Orser CS (1994) Survival of Pseudomonas spp. in air dried mineral powders. Soil Biol Biochem 26:1423-1430

Das BC, Khairuzzaman ASM, Bora LC (1998) Biological seed treatment for management of sheath blight of rice. J Mycol Plant Pathol 28(1):45-47

Datta SKD (1981) Diseases of rice and their control. In: Datta SKD (ed) Principles and practices of rice production. Wiley, New York, p 619

De Freitas JR, Banerjee MR, Germida JJ (1997) Phosphate solubilizing rhizobacteria enhance the growth and yield but not phosphorus uptake of canola (Brassica napus L.). Biol Fert Soil 24: 358-364

Dey R, Pal KK, Bhatt DM, Chauhan SM (2004) Growth promotion and yield enhancement of peanut (Arachis hypogaea L.) by application of plant growth-promoting rhizobacteria. Microbiol Res 159:371-394 
Dobereiner J, Day JM (1976) Associative symbiosis in tropical grasses: characterization of microorganisms and dinitrogen fixing sites. In: Newton WE, Nyman CJ (eds) Proceedings of the first international symposium on nitrogen fixation, vol 2. Washington State University Press, Pullman, pp 518-538

Duan G, Zhang Z, Zhang J, Zhou Y, Yu L, Yuan Q (2007) Evaluation of crude toxin and metabolite produced by Helminthosporium gramineum Rabenh for the control of rice sheath blight in paddy fields. Crop Prot 26(7):1036-1041

Esitken A, Karlidag H, Ercisli S, Turan M, Sahin F (2003) The effect of spraying a growth promoting bacterium on the yield, growth and nutrient element composition of leaves of apricot (Prunus armeniaca L. cv. Hacihaliloglu). Aust J Agric Res 54:377-380

Fages J (1994) Azospirillum inoculants and field experiments. In: Okon Y (ed) Azospirillum/plant associations. CRC Press, Boca Raton, FL, pp 87-109

FAOSTAT (2007) Food and Agriculture Organization of the United Nations. In: Food and Agricultural Commodities Production for the year 2007

Flaishman MA, Eyal ZA, Zilberstein A, Voisard C, Hass D (1996) Suppression of Septoria tritici blotch and leaf rust of wheat by recombinant cyanide producing strains of Pseudomonas putida. Mol Plant Microbe Interact 9:642-645

Gandhi A, Saravanakumar K (2009) Studies on shelf life of Azospirillum lipoferum, Bacillus megaterium and Pseudomonas fluorescens in vermicompost carrier. J Phytol 1(2):100-107

Garica JAL, Schloter M, Durkaya T, Hartmann A, Manero FJG (2003) Colonization of pepper roots by a plant growth promoting Pseudomonas fluorescens strain. Biol Fert Soils 37:381-385

Gaur AC (1990) Physiological functions of phosphate solubilizing micro-organisms. In: Gaur AC (ed) Phosphate solubilizing micro-organisms as biofertilizers. Omega Scientific Publishers, New Delhi, pp 16-72

Gillis M, Kresters K, Hoste B, Janssens D, Kropenstedt RM, Stephan MP, Teixeira KRS, Dobereiner J, De Lay J (1989) Acetobacter diazotrophicus sp. nov., a nitrogen fixing acetic acid bacterium associated with sugarcane. Int J Syst Bacteriol 39:361-364

Glick BR (1995) The enhancement of plant growth by free living bacteria. Can J Microbiol 41:109-117

Groth DE, Bond JA (2007) Effects of cultivars and fungicides on rice sheath blight, yield, and quality. Plant Dis 91(12):1647-1650

Gupta S, Arora DK, Srivastava AK (1995) Growth promotion of tomato plants by rhizobacteria and imposition of energy stress on Rhizoctonia solani. Soil Biol Biochem 27:1051-1053

Hamaoui B, Abbadi JM, Burdman S, Rashid A, Sarig S, Okon Y (2001) Effects of inoculation with Azospirillum brasilense on chickpeas (Cicer arietinum) and faba beans (Vicia faba) under different growth conditions. Agron Sustain Dev 21:553-560

Haque HMM, Akon MAH, Islam MA, Khalequzzaman KM, Ali MA (2007) Study of seed health, germination and seedling vigor of farmers produced rice seeds. Int J Sustain Crop Prod 2(4):34-39

He QF, Chen WL, Ma ZC (2002) Purification and properties of antagonistic peptide produced by Bacillus subtilis A30. Chin J Rice Sci 16(4):361-365

Jaizme-Vega MDC, Rodriguez-Romero AS, Guerra MSP (2004) Potential use of rhizobacteria from the Bacillus genus to stimulate the plant growth of micropropagated bananas. Fruits 59:83-90

Jayaraj J, Yi H, Liang GH, Muthukrishnan S, Velazhahan R (2004) Foliar application of Bacillus subtilis AUBS1 reduces sheath blight and triggers defense mechanisms in rice. Zeitsch Pflanzen Pflanz 111(2):115-125

Jeyarajan R, Nakkeeran S (2000) Exploitation of microorganisms and viruses as biocontrol agents for crop disease management. In: Upadhyay RK et al (eds) Biocontrol potential and their exploitation in sustainable agriculture. Kluwer Academic/Plenum Publishers, New York, USA, pp 95-116

Joo GJ, Kim YM, Lee IJ, Song KS, Rhee IK (2004) Growth promotion of red pepper plug seedlings and the production of gibberellins by Bacillus cereus, Bacillus macroides and Bacillus pumilus. Biotechnol Lett 26:487-491 
Kanjanamaneesathian M, Pengnoo KA, Nilratana L (1998) Screening of potential bacterial antagonists for control of sheath blight in rice and development of suitable bacterial formulations for effective application. Aust Plant Pathol 27:198-206

Kanjanamaneesathian M, Wiwattanapatapee R, Pengnoo A, Oungbho K, Chumthong A (2007) Efficacy of novel formulations of Bacillus megaterium in suppressing sheath blight of rice caused by Rhizoctonia solani. Plant Pathol J Faisalabad 6(2):195-201

Kapulnik Y, Kigel J, Okon Y, Nur I, Henis Y (1981) Effects of Azospirillum inoculation on some growth parameters and N-content of wheat, sorghum and panicum. Plant Soil 61:65-70

Kavitha K, Nakkeeran S, Chandrasekar G, Fernando WGD, Mathiyazhagan S, Renukadevi P, Krishnamoorthy AS (2003) Role of antifungal antibiotics, siderophores and IAA production in biocontrol of Pythium aphanidermatum inciting damping off in tomato by Pseudomonas chlororaphis and Bacillus subtilis. In: Proceedings of the 6th International workshop on PGPR, Organized by IISR, Calicut 5-10 October. pp. 493-497

Kazempour MN (2004) Biological control of Rhizoctonia solani, the causal agent of rice sheath blight by antagonistic bacteria in greenhouse and field conditions. Plant Pathol J 3(2):88-96

Kennedy IR, Tchan YT (1992) Biological nitrogen fixation in non-leguminous field crops: recent advances. Plant Soil 141:93-118

Khalid A, Arshad M, Zahir ZA (2003) Growth and yield response of wheat to inoculation with auxin producing PGPR. Pak J Bot 35:483-498

Kloepper JW, Scroth MN (1981) Development of a powder formulation of rhizobacteria for inoculation of potato seed pieces. Phytopathol 71:590-592

Kobayashi T, Mew TW, Hashiba T (1997) Relationship between incidence of rice sheath blight and primary inoculum in the Philippines: mycelia in plant debris and sclerotia. Ann Phytopathol Soc Jpn 63:324-327

Kokalis-Burelle N, Vavrina CS, Rosskopf EN, Shelby RA (2002) Field evaluation of plant growthpromoting rhizobacteria amended transplant mixes and soil solarization for tomato and pepper production in Florida. Plant Soil 2:257-266

Kozaka T (1961) Ecological studies on sheath blight of rice plant caused by Pellicularia sasakii and its chemical control. Chugoku Agric Res 20:1-13

Laha GS, Venkataraman S (2001) Sheath blight management in rice with biocontrol agents. Ind Phytopath 54(4):461-464

Lalande R, Bissonnette N, Coutlee D, Antoun H (1989) Identification of rhizobacteria from maize and determination of their plant-growth promoting potential. Plant Soil 115:7-11

Lee FN, Rush MC (1983) Rice sheath blight: a major rice disease. Plant Dis 67:829-832

Li XM, Hu BS, Xu ZG, Mew TW (2003) Threshold population sizes of Bacillus subtilis B5423-R to suppress the occurrence of rice sheath blight. Chin J Rice Sci 17(4):360-364

Lucas JA, Ramos Solano B, Montes F, Ojeda J, Megias M, Gutierrez Mañero FJ (2009) Use of two PGPR strains in the integrated management of blast disease in rice (Oryza sativa) in Southern Spain. Field Crops Res 114:404-410

Luo JY, Xie GL, Li B, Luo YC, Zhao LH, Wang X, Liu B, Li W (2005) Gram-positive bacteria associated with rice in China and their antagonists against the pathogens of sheath blight and bakanae disease in rice. Rice Sci 12(3):213-218

Malarvizhi R (1987) Biological control of sheath blight disease of rice caused by Rhizoctonia solani Kuhn with Pseudomonas fluorescens. Masters Dissertation, University of Madras

Mathivanan N, Prabavathy VR, Vijayanandraj VR (2006) Application of talc formulations of Pseudomonas fluorescens Migula and Trichoderma viride Pers. ex S.F. Gray decrease the sheath blight disease and enhance the plant growth and yield in rice. J Phytopathol 154(11/12):697-701

Mehnaz S, Mirza MS, Haurat J, Bally R, Normand P, Bano A, Malik KA (2001) Isolation and $16 \mathrm{~S}$ rRNA sequence analysis of the beneficial bacteria from the rhizosphere of rice. Can $\mathrm{J}$ Microbiol 47:110-117

Meunchang S, Thongra-ar P, Sanoh S, Kaewsuralikhit S, Ando S (2006) Development of rhizobacteria as a biofertilizer for rice production. In: Paper presented at International workshop 
on sustained management of the soil-rhizosphere system for efficient crop production and fertilizer use 16-20 October, Land Development Department, Bangkok, Thailand

Mew TW, Rosales AM (1986) Bacterization of rice plants for control of sheath blight caused by Rhizoctonia solani. Phytopathol 76:1260-1264

Mew TW, Rosales AM (1992) Control of Rhizoctonia sheath blight and other diseases by rice seed bacterization. In: Tjamos ES, Papavizas GC, Cook RJ (eds) Biological control of plant diseases. Plenum, New York, pp 113-123

Mew TW, Cottyn B, Pamplona R, Barrios H, Xiangmin L, Zhiyi C, Fan L, Nilpanit N, Arunyanart P, Kim PV, Du PV (2004) Applying rice seed-associated antagonistic bacteria to manage rice sheath blight in developing countries. Plant Dis 88:557-564

Mirza MS, Ahmad W, Latif F, Haurat J, Bally R, Normajd P, Malik KA (2001) Isolation, partial characterization, and the effect of plant growth-promoting bacteria (PGPB) on micropropagated sugarcane in vitro. Plant Soil 237:47-54

Mirza SM, Mehnaz S, Normand P, Combaret CP, Loccoz YM, Balley MKA (2006) Molecular characterization and PCR detection of a nitrogen-fixing Pseudomonas strain promoting rice growth. Biol Fertil Soils 43:163-170

Muhammad T, Sohail H, Malik KA, Hafeez FY (2007) Plant root associated bacteria for zinc mobilization in rice. Pak J Bot 39(1):245-253

Munir A, Munir I, Afrasyab S, Hasnain S (2003) Growth stimulatory effects of Azospirillum strains on Triticum aestivum and Vigna radiate. Biotechnol 2:198-205

Murphy JF, Reddy MS, Ryu CM, Kloepper JW, Li R (2003) Rhizobacteria-mediated growth promotion of tomato leads to protection against cucumber mosaic virus. Phytopathol 93:1301-1307

Muthukumarasamy R, Revathi G, Murthy V, Mala SR, Vadivelu M, Solayappa AR (1997) An alternate carrier material for bio-fertilizers. Cooperat Sugar 28:677-680

Nagarajkumar M, Bhaskaran R, Velazhahan R (2004) Involvement of secondary metabolites and extracellular lytic enzymes produced by Pseudomonas fluorescens in inhibition of Rhizoctonia solani, the rice sheath blight pathogen. Microbiol Res 159(1):73-81

Nagaraju P, Dronavalli N, Biradar DP (2002) Biological control of sheath blight (Rhizoctonia solani) in transplanted rice (Oryza sativa). Ind J Agric Sci 72(5):306-307

Nakkeeran S, Kavitha K, Mathivazhagan S, Fernando WGD, Chandrasekar G, Renukadevi P (2004) Induced systemic resistance and plant growth promotion by Pseudomonas chlororaphis strain PA-23 and Bacillus subtilis strain CBE4 against rhizome rot of turmeric (Curcuma longa L.). Can J Plant Pathol 26:417-418

Nakkeeran S, Dilantha Fernando WG, Siddiqui ZA (2005) Plant growth promoting rhizobacteria formulations and its scope in commercialization for the management of pests and diseases. In: Siddiqui ZA (ed) PGPR: biocontrol and biofertilization. Springer, Dordrecht, The Netherlands, pp 257-296

Nandakumar R, Babu S, Viswanathan R, Sheela J, Raguchander T, Samiyappan R (2001a) A new bio-formulation containing plant growth promoting rhizobacterial mixture for the management of sheath blight and enhanced grain yield in rice. BioControl 46(4):493-510

Nandakumar R, Babu S, Viswanathan R, Raguchander T, Samiyappan R (2001b) Induction of systemic resistance in rice against sheath blight disease by Pseudomonas fluorescens. Soil Biol Biochem 33:603-612

Omar I, O'Neill TM, Rossall S (2006) Biological control of Fusarium crown and root rot of tomato with antagonistic bacteria and integrated control when combined with the fungicide carbendazim. Plant Pathol 55:92-99

Pal R, Chakrabarti K, Chakraborty A, Chowdhury A (2005) Dissipation of pencycuron in rice plant. J Zhejiang Univ Sci 6B(8):756-758

Pan B, Bai YM, Leibovitch S, Smith DL (1999) Plant growth-promoting rhizobacteria and kinetin as ways to promote corn growth and yield in a short-growing-season area. Eur J Agron 11:179-186

Pathak A, Sharma A, Johri BN, Sharma AK (2004) Pseudomonas strain $\mathrm{GRP}_{3}$ induces systemic resistance to sheath blight in rice. Int Rice Res Not 29(1):35-36 
Pereira JAR, Cavalcante VA, Baldani JI, Dobereiner J (1988) Field inoculation of sorghum and rice with Azospirillum spp. and Herbaspirillum seropedicae. Plant Soil 110:269-274

Podile AR, Kishore AK (2006) Plant growth promoting rhizobacteria. In: Gnanamanickam SS (ed) Plant associated bacteria. Springer, Netherlands, p 195

Prabavathy VR, Narayanasamy M, Kandasamy M (2006) Control of blast and sheath blight diseases of rice using antifungal metabolites produced by Streptomyces sp. PM5. Biol Cont 39(3):313-319

Prasad B, Eizenga GC (2008) Rice sheath blight disease resistance identified in Oryza spp. accessions. Plant Dis 92:1503-1509

Preeti V, Reddy MS, Kavitha S, Velusamy P, PaulRaj RSD, Purushothaman SM, Priyadarisini VB, Bharathkumar S, Kloepper JW, Gnanamanickam SS (2002) Role of biological preparations in enhancement of rice seedling growth and grain yield. Curr Sci 83:1140-1143

Rabindran R, Vidhyasekaran P (1996) Development of a formulation of Pseudomonas fluorescens PfALR2 for management of rice sheath blight. Crop Prot 15(8):715-721

Radja Commare R, Nandakumar R, Kandan A, Suresh S, Bharathi M, Raguchander T, Samiyappan R (2002) Pseudomonas fluorescens based bio-formulation for the management of sheath blight disease and leaf-folder insect in rice. Crop Prot 21:671-677

Raj NS, Shetty NP, Shetty HS (2004) Seed bio-priming with Pseudomonas fluorescens isolates enhances growth of pearl millet plants and induces resistance against downy mildew. Int J Pest Manag 50:41-48

Raja P, Uma S, Gopal H, Govindarajan K (2006) Impact of bioinoculants on rice root exudates, biological nitrogen fixation and plant growth. J Biol Sci 6(5):815-823

Rangarajan S, Saleena LM, Nair S (2002) Diversity of Pseudomonas spp. isolated from rice rhizosphere populations grown along a salinity gradient. Microb Ecol 43:280-289

Reinhold-Hurek B, Hurek T, Gillis M, Hoste B, Vancanneyt M, Kersters K, de Ley J (1993) Azoarcus gen. nov., nitrogen-fixing proteobacteria associated with roots of Kallar grass (Leptochloa fusca (L.) Kunth), and description of two species, Azoarcus indigens sp. nov., and Azoarcus communis sp. nov. Int J Syst Bacteriol 43:574-584

Ren XP, Xie GL, Wang X (2006) Application and colonization of Pseudomonas aeruginosa ZJ1999 for biocontrol of Rhizoctonia solani, pathogen of rice sheath blight. Chin J Biol Cont 22(1):54-57

Saikia R, Kumar R, Arora DK, Gogoi DK, Azad P (2006) Pseudomonas aeruginosa inducing rice resistance against Rhizoctonia solani: Production of salicylic acid and peroxidases. Folia Microbiol 51(5):375-380

Saleh SA, Mekhemar GAA, Abo El-Soud AA, Ragab AA, Mikhaeel FT (2001) Survival of Azorhizobium and Azospirillum in different carrier materials: inoculation of wheat and Sesbania rostrata. Bull Fac Agric Univ Cairo 52:319-338

Sarmah DK (1999) Combined effect of Gliocladium virens and Bacillus subtilis on sheath blight of rice. J Agric Sci Soc N East India 12(2):271-273

Scher FM, Baker R (1982) Effect of Pseudomonas putida and a synthetic iron chelator on induction of soil suppressiveness to Fusarium wilt pathogens. Phytopathology 72:1567-1573

Shanahan P, O'Sullivan DJ, Simpson P, Glennon JD, O' Gara F (1992) Isolation of 2, 4-diacetylphloroglucinol from a fluorescent pseudomonad and investigation of physiological parameters influencing its production. Appl Environ Microbiol 58:353-358

Shanmugam P, Narayanasamy M (2009) Optimization and production of salicylic acid by rhizobacterial strain Bacillus licheniformis MML 2501. Int J Microbiol 6(1):94-98

Shishido M, Petersen DJ, Massicotte HB, Chanway CP (1996) Pine and spruce seedling growth and mycorrhizal infection after inoculating with plant growth promoting Pseudomonas strains. FEMS Microbiol Ecol 21:109-119

Singh R, Sinha AP (2005) Influence of time of application of Pseudomonas fluorescens in suppressing sheath blight of rice. Ind Phytopathol 58(1):30-34

Someya N, Nakajima M, Watanabe K, Akutsu K (2005) Synergistic antifungal activity of the culture filtrates of Serratia marcescens strain B2 and chemical fungicides against the sclerotial viability of the rice sheath blight pathogen, Rhizoctonia solani. Biocontrol Sci 10(3):97-100 
Suparyono Catindig JLA, Castilla NP, Elazequi FA (2003) International Rice Research Institute (IRRI). "Diagnostic summary of rice sheath blight: Mechanism of action". Rice Knowledge Bank

Thara KV, Gnanamanickam SS (1994) Biological control of rice sheath blight in India: lack of correlation between chitinase production by bacterial antagonists and sheath blight suppression. Plant Soil 160:277-280

Tripathi M, Munot HP, Schouche Y, Meyer JM, Goel R (2005) Isolation and functional characterization of siderophore-producing lead-and cadmium-resistant Pseudomonas putida KNP9. Curr Microbiol 50:233-237

Van Lai E, Nguyen TPL, Van Pham D, Mew TW (2001) Current status and future prospects in biological control of rice sheath blight in Mekong delta. Omonrice 9:79-86

Vasantha Devi T, Malarvizhi R, Sakthivel N, Gnanamanickam SS (1989) Biological control of sheath blight of rice in India with antagonistic bacteria. Plant Soil 119:325-330

Vidhyasekaran P, Muthamilan M (1995) Development of a formulation of Pseudomonas fluorescens for control of chickpea wilt. Plant Dis 79:782-786

Vijay Krishna Kumar K, Krishnam Raju S, Reddy MS, Kloepper JW, Lawrence KS, Groth DE, Miller ME, Sudini H, Binghai Du (2009) Evaluation of commercially available PGPR for control of rice sheath blight caused by Rhizoctonia solani. J Pure Appl Microbiol 3(2):485-488

Vleesschauwer DD, Hofte M (2005) Bacterial determinants involved in induced systemic resistance in rice. In: Gnanamanickam SS, Balasubramanian R, Anand N (eds) Asian conference on emerging trends in plant-microbe interactions. Chennai, India, pp. 1-4

Wang KW, Xiuyun Z, Xuedong W, Aiying L, Huazhu H (2009) The inhibitory activity of endophytic Bacillus sp. strain CHM1 against plant pathogenic fungi and its plant growthpromoting effect. Crop Prot 28:634-639

Weller DM (1983) Colonization of wheat roots by a fluorescent pseudomonad suppressive to take all. Phytopathol 73:1548-1553

Wiwattanapatapee R, Chumthong A, Pengnoo A, Kanjanamaneesathian M (2007) Effervescent fast-disintegrating bacterial formulation for biological control of rice sheath blight. J Control Rel 119(2):229-235

Yang CH, Crowley DE (2000) Rhizosphere microbial community structure in relation to root location and plant iron nutritional status. Appl Environ Microbiol 66(1):345-351 